\title{
The Impact of Integrating Technology in Teaching Listening Skill to Kurdish Students at Preparatory Schools
}

\section{Payam Aziz Muhammad Nawe}

English Department, College of Basic Education, Salahaddin University-Erbil. payam.muhammad@su.edu.krd.

\section{Wirya Omar Amin}

Jihan University-Erbi, Head of promotion

warriaamin@gmail.com

\section{ARTICLE INFO}

\section{Article History:}

Received: 08/10/2019

Accepted: $17 / 11 / 2019$

Published: Summer 2020

\section{Keywords:}

Listening,

Preparatory,

Technology,

students, motivate

Doi:

10.25212/Ifu.qzj.5.3.32

\begin{abstract}
The current study attempts to examine the effectiveness of embedding technology, as an essential topic for educators around the world, with teaching listening skill in the secondary phase for Kurdish students as a solution to motivate the teachers and students to focus on this skill. The traditional in-class vs. the technology-based learningusing approach is compared in an attempt to show how innovative approaches are fruitful. For this purpose, the researcher carried out a quasi-experimental study. Thus, a pre-test post-test research design is utilized, and the sample was taken from Mamun Dabakh preparatory public school for girls in Erbil city. The experiment lasted for eight weeks, and 40 students of the grade $10^{\text {th }}$ were divided into two groups, namely the experimental and the control group. The experimental group is taught by using technology, while the control group was taught traditionally which is reading aloud by the teacher in order to find out the practical techniques and strategies used by teachers in teaching listening skill via technology.
\end{abstract}


The data was collected from the students' pre-test posttest scores and students' online progress application, the study results obtained from statistical tests after applied to both control and experimental groups, through using SPSS v-25. So, to achieve that the descriptive statistics are used through statistical mean, standard deviation, t-test, and $p$-values, as well as charts of frequencies distributions and percentages. However, since the comparative analysis also used and the variability of the results reached, the findings are presented according to the study hypotheses. The main finding of this study suggests that using technology-assisted significantly enhance Kurdish EFL students' listening and that the experimental group outperformed the control group in their listening subskills.

\section{INTRODUCTION}

In the last recent years, Iraqi Kurdistan Region has witnessed educational changes in programs. In this regard, a new English course, called "Sunrise" has been implemented to develop Kurdish students' communicative competence in the target language. According to the principles of Communicative Language Teaching, for teaching English. The students and teachers are asked to practice all four skills during the lesson and equally in a testing scheme to develop their communicative skills. However, teachers mostly avoid teaching the listening skill to the students. Therefore, it has noted that students are not interested in learning all the skills of the English language, and the students tend to ignore this skill. Thus, the study deals with the effectiveness of technology on teaching listening skill in order to motivate teachers to attain the advantage of technology in their pedagogical teaching, and they should always abide themselves with new developments in language teaching practice because teaching is a platform which demands continual training and learning. The study focuses on issues related to the preparatory level of Kurdistan education and 


\section{QALAAI ZANISTSCIENTIFIC JOURNAL \\ A Scientific Quarterly Refereed Journal Issued by Lebanese French University - Erbil, Kurdistan, Iraq \\ Vol. (5), No (3), Summer 2020 \\ ISSN 2518-6566 (Online) - ISSN 2518-6558 (Print)}

the real problems that are barriers to teach this skill; the study is also an attempt to renovate this skill in Sunrise program.

\subsection{Definition of Basic Terms}

Integrating Technology: Using instrumental or informational technology

Preparatory School: The stages/levels from 10 till 12 grades in Kurdistan education system

Sunrise Program: The English program that is taught at all levels in Kurdistan.

\subsection{The Problem Statement}

In the Kurdistan Region, various attempts have been made to reform the school curriculum in general, and to enhance students' English and English language teaching in particular. One of the significant outcomes in this field is designing a SUNRISE program according to the principles of Communicative Language Teaching (henceforth CLT). So, this approach is introduced in Sunrise Series (1-12) levels, for teaching English, in Kurdistan educational system. The experience in teaching the English language has shown in almost all of the stages speaking, writing, and reading skills are given maximum opportunity to do. In addition to existing a large portion of listening skill from the curriculums. Nonetheless, teachers mostly avoid teaching the listening skill to the students. Thus, it has noted that students are not interested in learning all the skills of the English language, and the students tend to ignore this skill. While there might be some other researchers investigated the reason behind this abandoned skill, but the present study tries to address the problem of teaching listening in the secondary phase for Kurdish students. The traditional in-class vs. the technology-based learning-using approach is compared in an attempt to show how innovative approaches are fruitful. 


\section{QALAAI ZANISTSCIENTIFIC JOURNAL}

A Scientific Quarterly Refereed Journal Issued by Lebanese French University - Erbil, Kurdistan, Iraq

Vol. (5), No (3), Summer 2020

ISSN 2518-6566 (Online) - ISSN 2518-6558 (Print)

Table 1: Frequency Distribution and the Percentages of the Activities Used in Sunrise 10 - Student's Book.

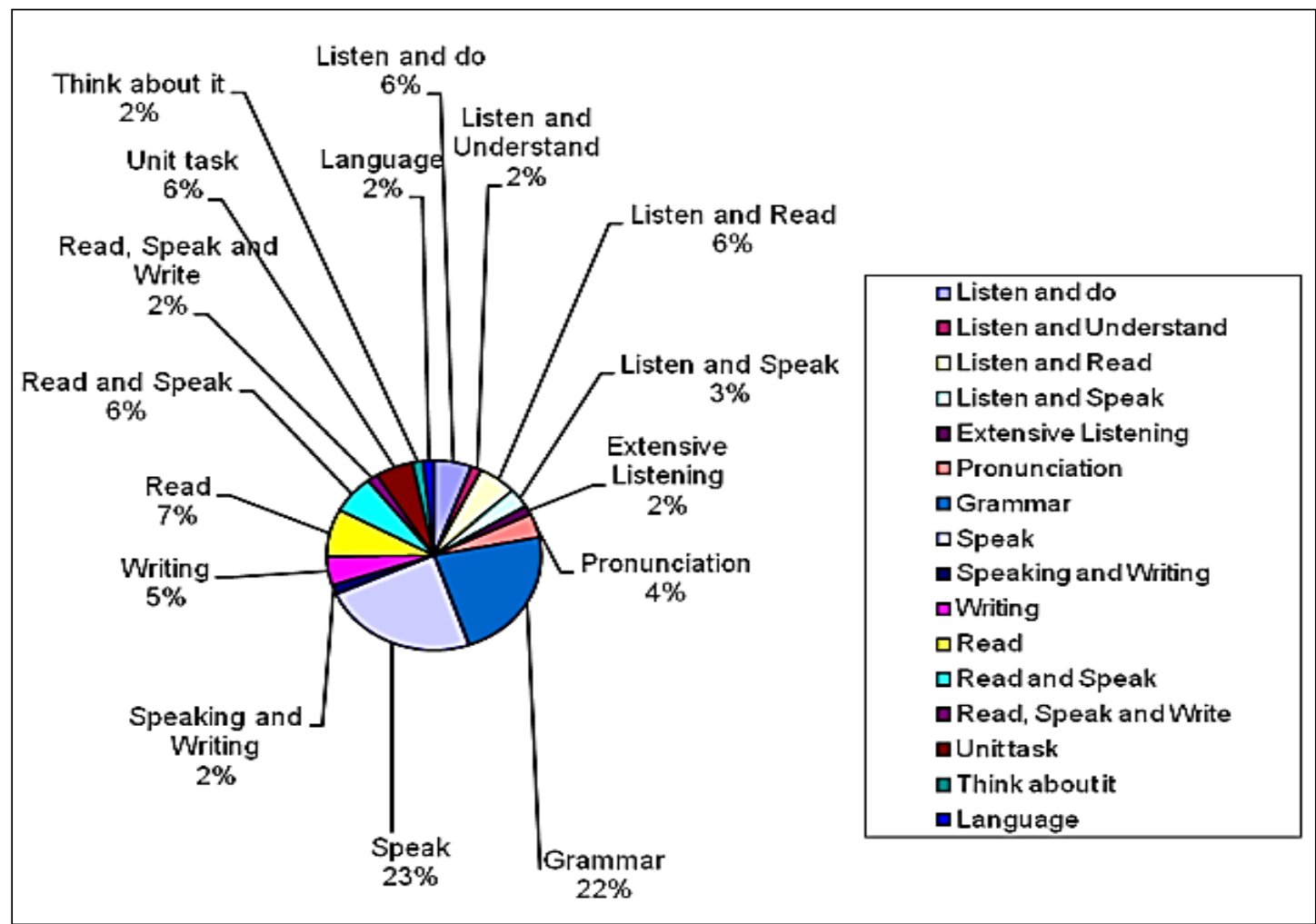

Source: Sultan, A. I., \& Sharif, H. A. (2013). The Efficiency of Teaching Listening Comprehension of "Sunrise Series" in Erbil Governorate. The Journal of the Literary Literature, 1(16), 1-42. And Sunris Series (Sunrise10, 2009)

Figure1, above shows that nearly (26\%) of the activities within Sunrise series are devoted to the Listening comprehension skill. Listening activities are either introduced individually or integrated with other skills, and they are to be taught according to the teaching tips provided in the teachers' Book. 


\section{QALAAI ZANISTSCIENTIFIC JOURNAL \\ A Scientific Quarterly Refereed Journal Issued by Lebanese French University - Erbil, Kurdistan, Iraq \\ Vol. (5), No (3), Summer 2020 \\ ISSN 2518-6566 (Online) - ISSN 2518-6558 (Print)}

\subsection{The Study Significant}

The present study significant embodied in its expected values to have for the ministry of education, specialists, supervisors as well as English language teachers in Kurdistan. Besides all those who work in the field of teaching and testing listening skill, as it motivates to raise this skill when they feel that it is significant in the field of their effort. However, paving the way to future studies related to the development of listening skill in other Kurdistan preparatory schools, particularly researchers in the field of applied linguistics.

\subsection{The Study Purposes}

The primary purpose of this study is to examine the impact of integrating technology in teaching listening skill to Kurdish students at preparatory schools in Erbil city. Thus, its effort to finding out the practical techniques and strategies used by teachers in teaching listening skill via technology. Besides exploring the influence of integrating technology into teaching listening skill with preparatory level students in Kurdistan. Furthermore, suggesting educational solutions and recommendations for such difficulties and challenges.

\subsection{Research Question}

Based on the problem outlined above, the current study arises out of the following questions:

1) What are the actual listening problems among students at Mamun Dabakh Preparatory School, in Erbil city?

2) What is the effect of using equipped class based on technology in developing students' listening skill at Mamun Dabakh preparatory school in Erbil city?

3) To what extent the mean score of the experimental student group in the pretest is different from the mean score of the controlled student group? 


\section{QALAAI ZANISTSCIENTIFIC JOURNAL \\ A Scientific Quarterly Refereed Journal Issued by Lebanese French University - Erbil, Kurdistan, Iraq \\ Vol. (5), No (3), Summer 2020 \\ ISSN 2518-6566 (Online) - ISSN 2518-6558 (Print)}

\subsection{The Study hypotheses}

The current study hypothesizes that:

1) The students face problems with listening skill while learning English.

2) Integrating technological means have no effects on developing students' listening skills post-test in favor of the experimental group.

3) There is no statistically significant difference between the mean scores of the experimental group and those of the control group in the listening skills of the pre-test (before experimental weeks).

\subsection{The Study Limitation}

This study is limited to secondary students (grade 10th) and Sunrise textbook 10 in Erbil city, in the academic year (2018-2019) for eight weeks, five sessions per a week according to the schools' schedule of English lesson. The current study is more limited to examine the impact of technology on solely the improvement of listening skill, apart from the other three; thus; the researcher could not spend more than this time with students. More extended periods of treatment may bring about different results. Another limitation has to do with the nature of the instruments used in the study.Given that listening comprehension usually poses a challenge to language learners, it was not possible to administer tests other than those contained in the textbook with which they usually dealt. Also, the researcher has chosen this school (Mamun Dabakh Preparatory School for Girls) for the following reasons:

a) The researcher has been teaching in this preparatory school since 2011,

b) Most of these facilities, which the researcher needs for the experimental study, have been provided but neglected. 


\section{QALAAI ZANISTSCIENTIFIC JOURNAL \\ A Scientific Quarterly Refereed Journal Issued by Lebanese French University - Erbil, Kurdistan, Iraq \\ Vol. (5), No (3), Summer 2020 \\ ISSN 2518-6566 (Online) - ISSN 2518-6558 (Print)}

c) The principle and directorate staffs of this school allow the researcher to take the students and their sessions; therefore, the headmaster has put as the schedule for teaching within the school time table.

\section{METHODOLOGY}

\subsection{The Study Method}

The current study generally comprises qualitative and quantitative methods, while conducting mixed methods research allowed for the identification of the convergence and divergence of qualitative and quantitative data, contributing to results that mutually complement each other. Integration of qualitative and quantitative methods opened up for the researchers a greater overall understanding. Thus, contributing to results that mutually complement each other and the advantage of integrating both of the methods in studies is that they recognize the value of iterating between that which can be counted and that which cannot in order to generate more precious insights about the phenomena of interest (Kaplan, 2015). As the challenges encountered by Kurdish students in their actual daily teaching when utilizing the technology with their lessons, the qualitative research sounds to be suitable for achieving this aim in order to acquire an in-depth understanding of these challenges in reality. The researcher has taken this method by jolting down the notes, dairy, taken photo, portfolio to obtain the first research question. In addition to the content analysis of sunrise ten about listening parts, the researcher has carried out the quantitative approach as well, to obtain the other research question through the experimental teaching because as (Zhawawi, 2019, p. 79), cited on Leedy and Ormrod, highly recommended to the researchers. Accordingly, as to utilize an experiment in educational research when exploring the effectiveness of using specific techniques on students' progress identically and to find out the relationship between the variables, the merging technology with listening skill in the students' English lessons is the independent variable, and the students' progress in this skill becomes the dependent variable. 


\section{QALAAI ZANISTSCIENTIFIC JOURNAL \\ A Scientific Quarterly Refereed Journal Issued by Lebanese French University - Erbil, Kurdistan, Iraq \\ Vol. (5), No (3), Summer 2020 \\ ISSN 2518-6566 (Online) - ISSN 2518-6558 (Print)}

\subsection{Research Design}

To be able to understand about which design of experiments the researcher should be following, the related and close literature have reviewed, can get a decision that quasi-experimental designs as a possible settlement between scientific experimentation and the nature of human language behavior which applied linguistics want to investigate (Zhawawi, 2019). Consequently, this study is quasiexperimental in design, while it allows the researcher to compare groups behaviors within controlled teaching settings using the entire group. However, this study comprises the pre-test and post-test design. In this regard, the study sampling was systematically selected. So, a selected group of 40 students of the grade 10th at Mamun Dabakh preparatory school for girls in Erbil city. '

\subsection{The Study Participants}

The study participants are 44 students of the grade 10th at Mamun Dabakh preparatory school in Erbil city. While the overall number of the students of grade 10th in this preparatory is nearly 112 girls, during the academic year 2018-2019. However, their age approximately ranged between (16-18) years. Moreover, to prevent the effect of gender difference on the results of the study, this variable was held constant among all participants, and all the subjects were selected among female students. Nevertheless, some of the students did not participate in the tests, online practices, attention in the class sessions; they need the motivation to take part for each session particularly the control group; hence the final pool of participants consisted of 40 students and divided into two separate groups; namely control group of 20 students, and then experimental group of 20 students. The percentage of the sample was $40 \%$ of the population.

\subsubsection{The Control Group}

Commonly, each group either experimental or control group were taught and given the same material, instructions and learning syllabus except that this group (CG) was 


\section{QALAAI ZANISTSCIENTIFIC JOURNAL \\ A Scientific Quarterly Refereed Journal Issued by Lebanese French University - Erbil, Kurdistan, Iraq \\ Vol. (5), No (3), Summer 2020 \\ ISSN 2518-6566 (Online) - ISSN 2518-6558 (Print)}

not exposed to teach them through technology inside the class and they were not provided by giving them the online codes to practice their listening skill at home. On the other hand, they were taught by the traditional way of listening skill such as focusing on reading aloud the texts and transcripts by the teacher, dictation for eight weeks, three sessions of English language for each week.

\subsubsection{The Experimental Group}

On the contrary of the control group, this group (ExG) of students was taught via modern technology either the instructional technology such as smartboard, projector, computer, and laptop, or information technology as online practice, Viber broadcast group, and websites. Thus, they were familiarized with the duration of the experiment, during eight weeks and 5 English language sessions per week. Mainly, the researcher has taken into consideration these tips in order to avoid any bias and thread into the internal validity of the research. Both of the group students were the same age, teaching the same content from their textbook (Sunrise 10), the same length of teaching time, and she has taught both of the groups by herself despite different teaching techniques and tools.

\subsection{The Model Adopted}

Model of each research is utilized to describe the overall framework used to look at reality. The existence of a tentative model helps in choosing the logical structure of the complete research project and planning it. The model helps to make mind up that material has to be collected (Clarke, 2005). Based on this statement, the researcher adopts to base her research on Madsen's model to categorize the test. According to Madsen (1983, p.127), there are two broad categories of tests that incorporate the listening skill (low-level proficiency -recognition) and (high-level proficiency production). 


\section{QALAAI ZANISTSCIENTIFIC JOURNAL \\ A Scientific Quarterly Refereed Journal Issued by Lebanese French University - Erbil, Kurdistan, Iraq \\ Vol. (5), No (3), Summer 2020 \\ ISSN 2518-6566 (Online) - ISSN 2518-6558 (Print)}

\subsection{Data Collection and Instrument}

The students' answers to the tests administered and the researcher's observation during eight weeks of teaching is the data source for the present study. The scores of the pre-test and post-test which are compared their means. So, as the instrument, the researcher also implemented both traditional teachings in class and integrating technological means.

\subsection{Reliability of the Tool}

A significant principle in any test is reliability for evaluating any test it must not only be valid but it must also have reliability, a test, a data-coding system, or an attitude measurement can be measured as 'reliable' if it can be trusted to work (giving similar results) under varying conditions (with different scores) (Johnson \& Johnson, 1999). To gauge the reliability of the tool in this study, the inter-rater type of reliability is used in order to denote the extent to which the same marks or grades are awarded if the test paper is marked by the two or more different scorers or the same examiner on different occasions (Heaton, 1988). So, the answer sheets scored in two different times by the researcher firstly and secondly by another English teacher who has been teaching Sunrise 10 in the Academic year 2018-2019. For this purpose, the typical answers were provided and available from the teachers' book, to avoid subjectivity in scoring.

\section{DATA ANALYSIS AND RESULTS DISCUSSION}

The main aim of this section is to discuss the results that obtain from statistical tests, after applied to both control and experimental groups, through using SPSS v-25. So, to achieve that the descriptive statistics are used through statistical mean, standard deviation, t-test, and p-values, as well as charts of frequencies distributions and percentages. However, since the comparative analysis also used and the variability of the results reached, the findings are presented according to the study hypotheses. 


\section{QALAAI ZANISTSCIENTIFIC JOURNAL \\ A Scientific Quarterly Refereed Journal Issued by Lebanese French University - Erbil, Kurdistan, Iraq \\ Vol. (5), No (3), Summer 2020 \\ ISSN 2518-6566 (Online) - ISSN 2518-6558 (Print)}

\subsection{Hypotheses Testing}

\subsubsection{Testing the First Hypothesis}

To examine the study first hypothesis states that the students at preparatory schools faced listening problems while learning English. While according to Bond (2012), listening recognizes as the receptive side of the oral communication of the language besides it means the ability to understand the vocal part. However, the means of conveying language orally is not the only concept of meaning, but also the explanation, judgment, analysis, and estimation of the spoken words. The mean scores of the control group from both pre- and post-tests were compared.

Table 2: Results of paired samples statistics of the control group (pre- and post-tests at total scores)

\begin{tabular}{lllllll}
\hline & Group Type & N & Mean & $\begin{array}{l}\text { Std. } \\
\text { Deviation }\end{array}$ & T-test & P-value \\
\hline $\begin{array}{l}\text { Prests } \\
\text { Post-test (Total Level) }\end{array}$ & & 20 & 19.60 & 8.146 & 2.745 & \\
& CG & & & & 0.013 \\
& CG & 20 & 28.45 & 14.641 & & \\
\hline
\end{tabular}

As Table 2, presented that the post-test statistical mean scores (28.45) of the students who received only the lessons through the traditional teaching in class, but not the technology-based learning, while they took tests from (60) scores, it means that the results are not significantly differenced from their pre-test mean scores (19.60). However, the p-value is equal to $(0.013)$, which is less than the significance level (0.05), therefore, it can be recognized that there are not stratified results in the control group, hence first hypothesis accepted that indeed the students at preparatory schools faced listening problems during learning English, as total scores revealed in Chart 1, below. 


\section{QALAAI ZANISTSCIENTIFIC JOURNAL}

A Scientific Quarterly Refereed Journal Issued by Lebanese French University - Erbil, Kurdistan, Iraq

Vol. (5), No (3), Summer 2020

ISSN 2518-6566 (Online) - ISSN 2518-6558 (Print)

\subsection{5}

30

25

20

15

10

5

0

19.6

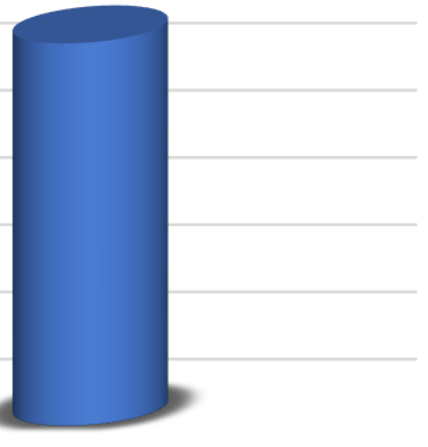

Pre-test (Total Level)

Post-test (Total Level)

Chart 1: Control group's per- and post-tests total scores

As shown in Table 3, and related Chart 2, below the results of both tests, namely pretest and post-test of the control group at the partial level or individuals revealed that most students at preparatory schools within this group did not achieve improvement in their listening skills. As mentioned by Sheir et al. (2013), students at preparatory schools stated that they faced listening problems while learning English; therefore, they might not recall words and phrases that they heard only. So, it was one of the most common complaints reported by students, although most students could understand what was said when they heard it, they forget it once they started listening to another part of the message. However, in the context of listening problems, Sultan and Sharif (2013), argued that educating listening comprehension is undoubtedly a challenging task not only for students at preparatory schools but also for teachers. Transient nature makes it difficult for students at preparatory schools to concentrate attention on a particular word or phrase for a detailed clarification, analysis, and estimation of the spoken words. Hence, it is logical that many teachers are entering the listening comprehension test for students rather than teaching them effectively. 


\section{QALAAI ZANISTSCIENTIFIC JOURNAL}

A Scientific Quarterly Refereed Journal Issued by Lebanese French University - Erbil, Kurdistan, Iraq

Vol. (5), No (3), Summer 2020

ISSN 2518-6566 (Online) - ISSN 2518-6558 (Print)

Table 3: Control group's per- and post-tests individual scores

\begin{tabular}{|c|c|c|c|c|c|}
\hline \multirow[b]{2}{*}{$\begin{array}{l}\text { Participant's' } \\
\text { Code }\end{array}$} & \multicolumn{5}{|l|}{ CG } \\
\hline & $\begin{array}{l}\text { Pre-test } \\
\text { Total Scores }\end{array}$ & $\begin{array}{l}\text { Post-test } \\
\text { Total Scores }\end{array}$ & $\begin{array}{l}\text { Participant's' } \\
\text { Code }\end{array}$ & $\begin{array}{l}\text { Pre-test } \\
\text { Total } \\
\text { Scores }\end{array}$ & $\begin{array}{l}\text { Post-test } \\
\text { Total } \\
\text { Scores }\end{array}$ \\
\hline G10S1 & 29 & 40 & G10S10 & 10 & 9 \\
\hline G10S2 & 25 & 44 & G10S11 & 19 & 15 \\
\hline G10S3 & 14 & 35 & G10S12 & 12 & 14 \\
\hline G10S4 & 22 & 19 & G10S13 & 14 & 24 \\
\hline G10S5 & 12 & 22 & G10S14 & 12 & 50 \\
\hline G10S6 & 27 & 27 & G10S15 & 11 & 9 \\
\hline G10S7 & 29 & 14 & G10S16 & 11 & 18 \\
\hline G10S8 & 15 & 15 & G10S17 & 27 & 22 \\
\hline G10S9 & 8 & 5 & G10S18 & 27 & 30 \\
\hline
\end{tabular}

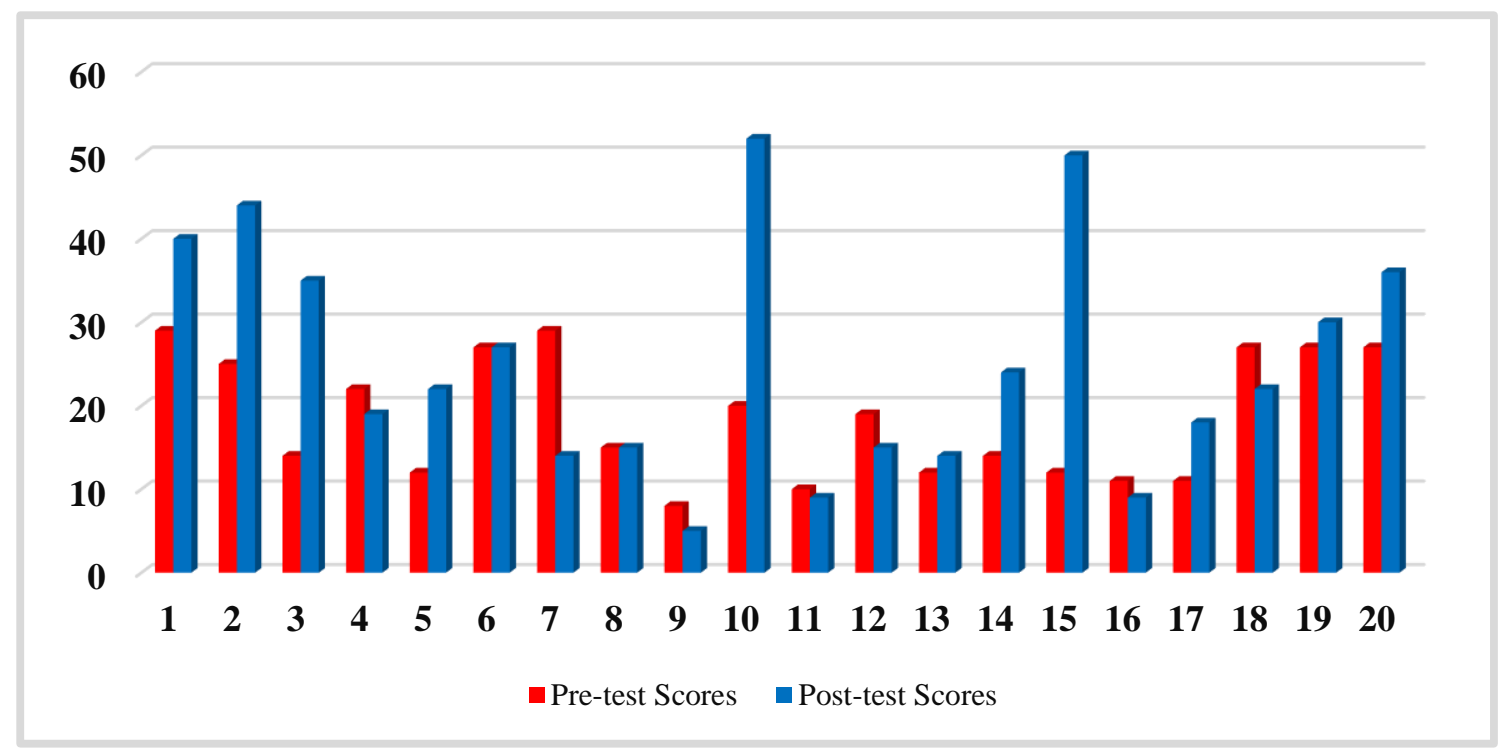

Chart 2: Control group's per- and post-tests Scores

In this regard, it can be stated that lessons through traditional teaching in class without utilizing modern teaching tools at low, medium, and advanced levels may be 


\section{QALAAI ZANISTSCIENTIFIC JOURNAL \\ A Scientific Quarterly Refereed Journal Issued by Lebanese French University - Erbil, Kurdistan, Iraq \\ Vol. (5), No (3), Summer 2020 \\ ISSN 2518-6566 (Online) - ISSN 2518-6558 (Print)}

no longer useful and dependable. So, the approaches that are utilized for giving listening activities by educators are the traditional method, which is teacher-centered (Sultan \& Sharif, 2013). While the results similar to some relevance researches like Sheir et al. (2013), found several problems related to teaching listening of the students at preparatory schools. Most notably, teachers were not in proper conscious of the importance of teaching listening and of the solid teaching materials used in teaching English. However, some teachers not using tape recorders.

\subsubsection{Testing the Second Hypothesis}

To explore whether the students within the experimental group improved their listening skill after receiving the lessons through the modern teaching instruments in class vs. the technology-based learning-using approach including online practice that are compared in an attempt to show how innovative approaches are more fruitful for students. As well as testing the second hypothesis stated that integrating technological means have no effects on developing students' listening skills post-test in favor of the experimental group.

As results shown in Table 4, the post-test mean score (43.35) of the students who took place in the experimental group. Besides, pre-test mean scores (19.35), the pvalue is equal to (0.000), less than the significance level $(0.05)$, hence, it can be confirmed that the students in the experimental group achieved significant improvement, in other words, there are significant differences in the experimental group's listening skill improvement. Thus, the second hypothesis rejected, and the alternative hypothesis accepted that integrated technological means have significant effects on developing students' listening skills at preparatory schools while learning English, as total scores revealed in Chart 3, below. 


\section{QALAAI ZANISTSCIENTIFIC JOURNAL}

A Scientific Quarterly Refereed Journal Issued by Lebanese French University - Erbil, Kurdistan, Iraq

Vol. (5), No (3), Summer 2020

ISSN 2518-6566 (Online) - ISSN 2518-6558 (Print)

Table 4: Results of paired samples statistics of the experimental group (pre- and posttests at total scores)

\begin{tabular}{lllllll}
\hline & Group Type & $\mathbf{N}$ & Mean & $\begin{array}{l}\text { Std. } \\
\text { Deviation }\end{array}$ & T-test & P-value \\
\hline $\begin{array}{l}\text { Prests } \\
\begin{array}{l}\text { Post-test (Total Level) } \\
\end{array}\end{array}$ & 20 & 19.35 & 7.087 & & \\
& ExG & & & & & \\
\cline { 2 - 5 } & ExG & 20 & 43.35 & 11.013 & & \\
& & & & & \\
\hline
\end{tabular}

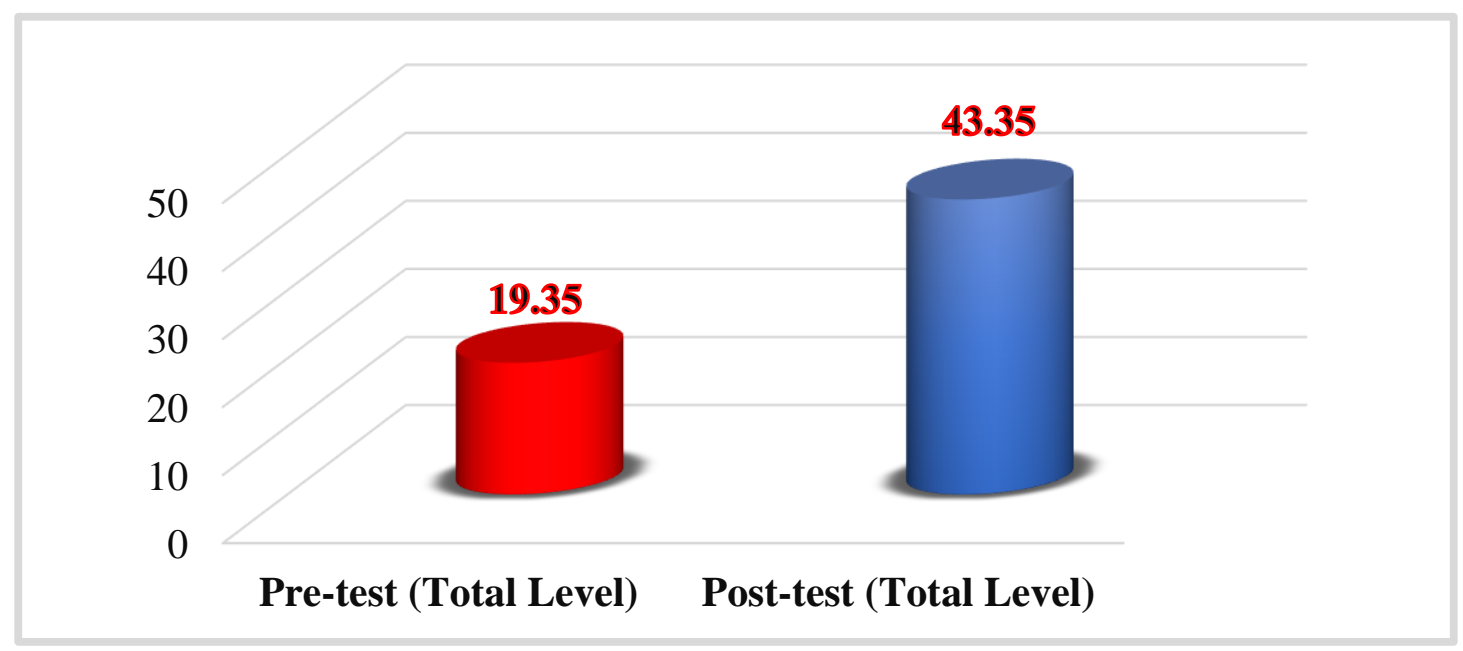

Chart 3. Experimental group's per- and post-tests total scores

When we look at the student's results of the experimental group separately, we can realize that most students or (95\%) of the total students at preparatory schools within this group achieved significant improvement in their listening skills. So, it can be confirmed that lessons through functioning modern teaching tools at low levels such as tape recorder and radio, besides medium likes computer/ laptop and sound laboratory, as well as advanced level like smart board in parallel to online practices, are innovative approaches and more fruitful for students, as revealed in Table 5, and related Chart 4 . The results also showed students make a significant positive impact 
of the online practice within (ExG) group. Accordingly, the researcher has utilized online practice in order to make the connection between the class with the home. There were many, and various types of program that the teachers can use to this aim, but the reason behind utilizing this program (Raz-kids) is that; it is easy to use, affordability to provide, appropriate the level from beginners till upper intermediate. So, the teacher can add the students according to their levels, then automatically the program presents level up to progress to their improvement in any language categories daily, weekly, monthly, and even year.

While Raz-kids delivers hundreds of interactive, leveled eBooks, four hundred eBooks and open-book e-quizzes with new books added every month (Anon, 2019), corresponding e-quizzes test comprehension, providing teachers with reports for data-driven instruction, besides online running records let the teachers digitally assess each student, saving valuable classroom time and engage them at home to use technology for the sake of learning. The motivation to get them the stars, rockets gets students excited about listening and reading - the award-winning website where students go to read - anytime, anywhere. 


\section{QALAAI ZANISTSCIENTIFIC JOURNAL}

A Scientific Quarterly Refereed Journal Issued by Lebanese French University - Erbil, Kurdistan, Iraq

Vol. (5), No (3), Summer 2020

ISSN 2518-6566 (Online) - ISSN 2518-6558 (Print)

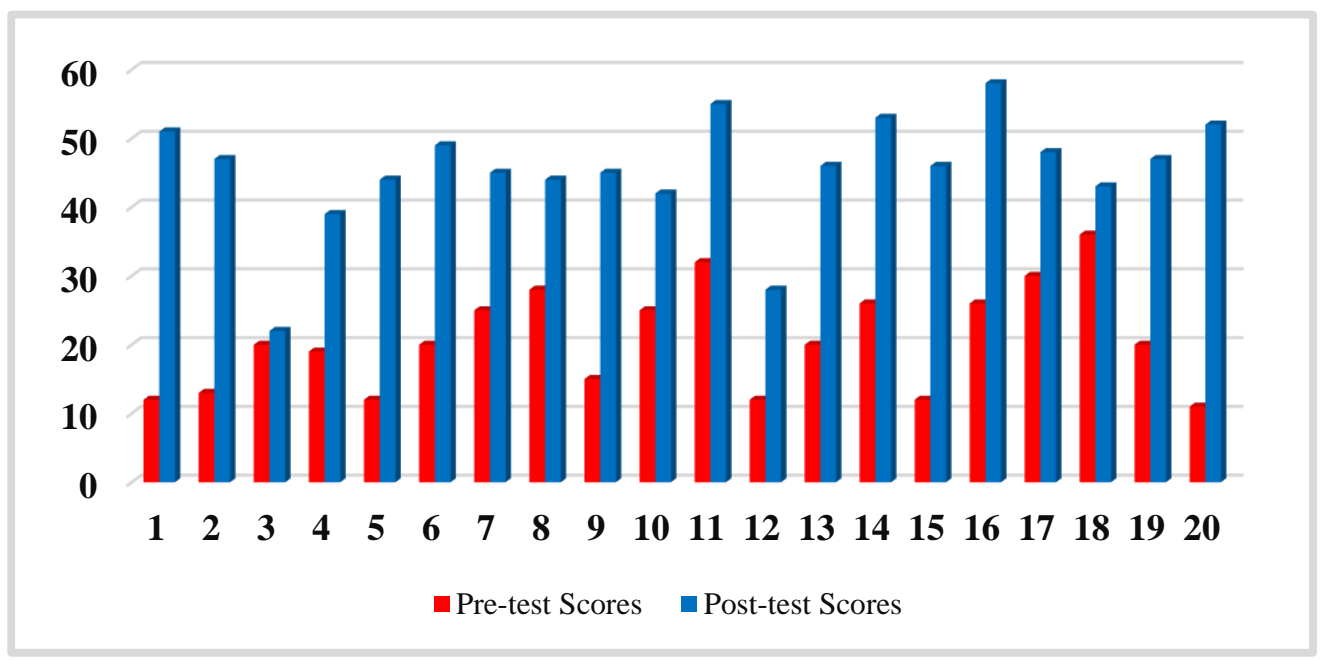

Chart 4. Experimental group's per- and post-tests individual scores

Table 5. Experimental group's per- and post-tests individual scores

\begin{tabular}{lll|llc}
\hline \multirow{3}{*}{$\begin{array}{l}\text { Participant's' } \\
\text { Code }\end{array}$} & ExG & \multicolumn{5}{l}{} \\
\cline { 2 - 6 } & $\begin{array}{l}\text { Pre-test } \\
\text { Total Scores }\end{array}$ & $\begin{array}{l}\text { Post-test } \\
\text { Total Scores }\end{array}$ & $\begin{array}{l}\text { Participant's' } \\
\text { Code }\end{array}$ & $\begin{array}{l}\text { Pre-test } \\
\text { Total Scores }\end{array}$ & $\begin{array}{l}\text { Post-test } \\
\text { Total Scores }\end{array}$ \\
\hline G10S1 & 12 & 51 & G10S11 & 32 & 55 \\
G10S2 & 13 & 47 & G10S12 & 12 & 28 \\
G10S3 & 20 & 22 & G10S13 & 20 & 46 \\
G10S4 & 19 & 39 & G10S14 & 26 & 53 \\
G10S5 & 12 & 44 & G10S15 & 12 & 46 \\
G10S6 & 20 & 49 & G10S16 & 26 & 58 \\
G10S7 & 25 & 45 & G10S17 & 30 & 48 \\
G10S8 & 28 & 44 & G10S18 & 36 & 43 \\
G10S9 & 15 & 45 & G10S19 & 20 & 47 \\
G10S10 & 25 & 42 & G10S20 & 11 & 52 \\
\hline
\end{tabular}

\subsubsection{Testing the Third Hypothesis}

As previously mentioned, the third hypothesis stated that there is no statistically significant difference between the mean scores of the experimental group and those of the control group in the listening skills of the pre-test (before experimental weeks). 


\section{QALAAI ZANISTSCIENTIFIC JOURNAL}

A Scientific Quarterly Refereed Journal Issued by Lebanese French University - Erbil, Kurdistan, Iraq

Vol. (5), No (3), Summer 2020

ISSN 2518-6566 (Online) - ISSN 2518-6558 (Print)

As the results are shown in Table 6, the mean and standard deviation score of ExG overall scores in the pre-test, are $(19.35$, and 7.087$)$ respectively, besides the mean score and standard deviation value of control group (CG) total scores in the pre-test, are $(19.60$, and 8.146$)$ respectively. So, these results revealed that there are no differences in both groups scores in the pre-test, t-test (2.104) and p-value same at (0.000). However, the test outcome scores indicated that students at preparatory schools faced listening problems while learning English.

Table 6: Students' (CG and ExG) Overall Scores in the Listening Skill Test

\begin{tabular}{|c|c|c|c|c|c|c|}
\hline $\begin{array}{l}\text { Tests } \\
\text { Achievements }\end{array}$ & $\begin{array}{l}\text { Group } \\
\text { Type }\end{array}$ & $\mathbf{N}$ & $\begin{array}{l}\text { Statistical } \\
\text { Mean }\end{array}$ & $\begin{array}{l}\text { Std. } \\
\text { Deviation }\end{array}$ & T-test & P-value \\
\hline \multirow{2}{*}{$\begin{array}{l}\text { Achievements in } \\
\text { the Pre-test } \\
\text { (Total Level) }\end{array}$} & CG & 20 & 19.60 & 8.146 & \multirow[b]{2}{*}{2.104} & \multirow[b]{2}{*}{0.000} \\
\hline & ExG & 20 & 19.35 & 7.087 & & \\
\hline \multirow{2}{*}{$\begin{array}{l}\text { Achievements in } \\
\text { the Post-test } \\
\text { (Total Level) }\end{array}$} & CG & 20 & 28.45 & 14.641 & \multirow[b]{2}{*}{3.637} & \multirow[b]{2}{*}{0.061} \\
\hline & ExG & 20 & 43.35 & 11.013 & & \\
\hline
\end{tabular}

The results in post-test indicated that the ExG obtained highest scores, the mean and standard deviation score of ExG overall scores in the post-test, are (43.35, and 11.013) respectively, then the mean and standard deviation score of CG total scores in the post-test, are (28.45, and 14.641$)$ respectively, with a t-test (3.637) and P-value is (0.061). The results revealed significant differences between both groups EXG and CG students test scores in their post-test that in favor of students in ExG who received lessons through using modern teaching tools in parallel to online practices, as shown in Chart 5, below. 


\section{QALAAI ZANISTSCIENTIFIC JOURNAL}

A Scientific Quarterly Refereed Journal Issued by Lebanese French University - Erbil, Kurdistan, Iraq

Vol. (5), No (3), Summer 2020

ISSN 2518-6566 (Online) - ISSN 2518-6558 (Print)

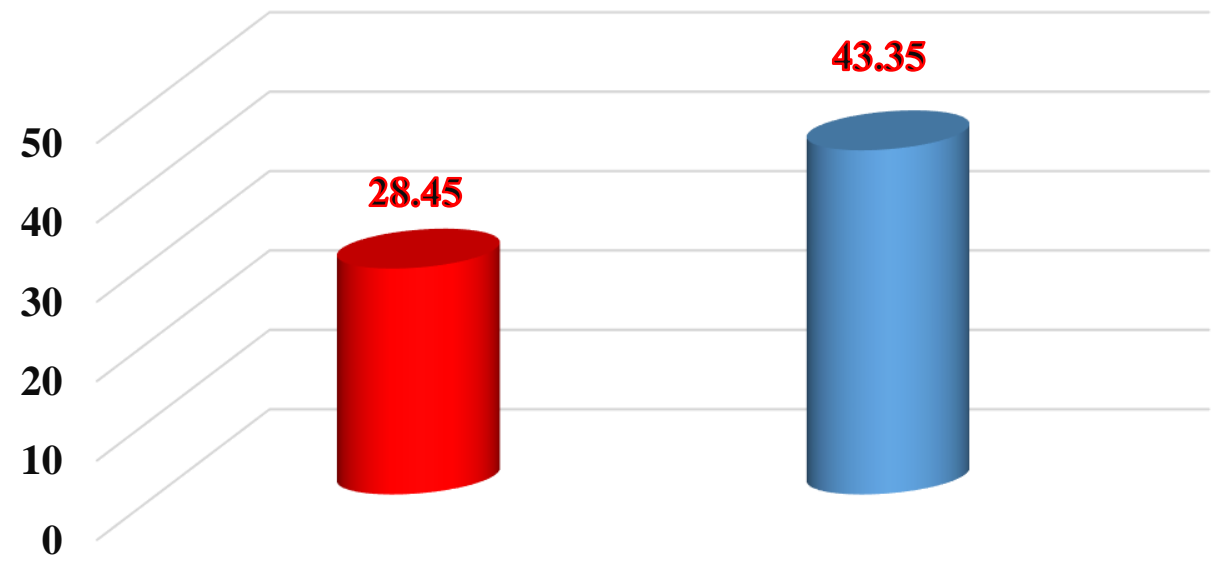

Post-test Control Group Post-test Experimental

Group

Chart 5: CG and ExG Post-test Overall Scores

The tests questions divided into two ways, according to education program in public schools in Kurdistan Region, these are writing (productive way) and picking up (receptive) the first one contains written and productive skill, while the second style comprises multiple-choice, matching, optics, and recognition skill. So, to investigate the students most improvement in their listening skills or the problems they faced while learning English, we have tested the CG and ExG scores based on these two different ways as they have been mentioned above.

As the results presented in Table 7, the mean and standard deviation of ExG in the pre-test, the traditional way is $(7.350$ and 4.8043$)$ respectively, besides the mean and standard deviation scores of the same group in the pre-test, the modern way is (13.150 and 6.0024) respectively. So, the results revealed that there are differences of this group's scores in the post-test, while the mean and standard deviation for the classical way is (20.150 and 5.6591) respectively and for the modern way are (25.450 and 4.2978) respectively, it means that students in ExG group more preferred in modern way and achieved significance improvement. 


\section{QALAAI ZANISTSCIENTIFIC JOURNAL \\ A Scientific Quarterly Refereed Journal Issued by Lebanese French University - Erbil, Kurdistan, Iraq \\ Vol. (5), No (3), Summer 2020 \\ ISSN 2518-6566 (Online) - ISSN 2518-6558 (Print)}

The results of the CG in the pre-test classical way indicated that the students in the control group did not obtain high scores, the mean and standard deviation for the classical way is (4.650 and 2.8887) ) respectively, however, the mean and standard deviation values of the same group in the pre-test, modern way is (13.900 and 6.0341) respectively. They are comparing to their scores in the post-test students in this group indeed achieved progress but not significantly. So, in the post-test, the mean and standard deviation for the traditional way is (6.600 and 7.3154) respectively, further the mean and standard deviation score of CG in the post-test, modern way is (18.400 and 7.1259) respectively. The test outcome scores indicated that students at preparatory schools more preferred in a modern way than classical one during learning English, as showed in Table 6. Therefore, the third hypothesis rejected and the alternative hypothesis accepted that there is a statistically significant difference between the mean scores of the experimental group and those of the control group in the listening skills of the pre-test (before experimental weeks). It means that using technology-assisted significantly enhance Kurdish EFL students' listening and that the experimental group outperformed the control group in their listening sub-skills.

Table 7: Comparative analysis of the CG and ExG Scores in the classical and modern ways

\begin{tabular}{|c|c|c|c|c|c|}
\hline & Tests Achievements & Type of Test & $\mathbf{N}$ & $\begin{array}{l}\text { Statistical } \\
\text { Mean }\end{array}$ & Std. Deviation \\
\hline \multirow{4}{*}{ CG } & \multirow[t]{2}{*}{ Achievements in the Pre-test } & $\begin{array}{l}\text { Reception } \\
\text { production }\end{array}$ & 20 & 4.650 & 2.8887 \\
\hline & & & 20 & 13.900 & 6.0341 \\
\hline & \multirow{2}{*}{$\begin{array}{l}\text { Achievements in the Post- } \\
\text { test }\end{array}$} & Reception & 20 & 6.600 & 7.3154 \\
\hline & & production & 20 & 18.400 & 7.1259 \\
\hline \multirow{5}{*}{ ExG } & \multirow[t]{3}{*}{ Achievements in the Pre-test } & Reception & & 7.350 & 4.8043 \\
\hline & & Production & 20 & & \\
\hline & & & 20 & 13.150 & 6.0024 \\
\hline & \multirow[t]{2}{*}{$\begin{array}{l}\text { Achievements in the Post- } \\
\text { test }\end{array}$} & Reception & 20 & 20.150 & 5.6591 \\
\hline & & Production & 20 & 25.450 & 4.2978 \\
\hline
\end{tabular}




\section{QALAAI ZANISTSCIENTIFIC JOURNAL \\ A Scientific Quarterly Refereed Journal Issued by Lebanese French University - Erbil, Kurdistan, Iraq \\ Vol. (5), No (3), Summer 2020 \\ ISSN 2518-6566 (Online) - ISSN 2518-6558 (Print)}

\section{CONCLUSIONS AND RECOMMENDATIONS}

\subsection{Conclusions}

This study is carried out to examine the impact of integrating technology in teaching listening skill to Kurdish students at preparatory schools in Erbil city. Consequently, based on the study finding which obtained through statistical tests, these conclusions are drawn:

1. As the main aim of the study tries to investigate the impact of technology on teaching LC, it looks for evidence to demonstrate its importance, thus through the results it sheds light on that point, which is teaching English language in Kurdistan needs to concentrate on using technology to come out of the dull traditional way of teaching

2. The students of ExG has shown a significant improvement in acquiring LC. The post-test and online practice results reported that students had improved from beginner to intermediate level skill in LC. It means teaching listening skill as FL/SL through technology-based learning inside the class or outside the class is more effective rather than teaching through the traditional way. Therefore, the students of ExG, which has exposed with modern approach (utilizing technology), has a significant enhancement rather than $C G$, which has exposed with the traditional way (reading aloud by the teacher).

3. Utilizing the technology with teaching listening skill can enhance the five skills discussed in this study.

4. Students generally were deficient in comprehending and understanding the English language and in LC, as their marks revealed it with CG.

5. LC is excluded from the exams (LC is less paid attention to than other language areas and skills). As a result, it is neglected to teach and has been a challenge for L2 learners; hence, there is no good coordination between MOE and the 


\section{QALAAI ZANISTSCIENTIFIC JOURNAL \\ A Scientific Quarterly Refereed Journal Issued by Lebanese French University - Erbil, Kurdistan, Iraq \\ Vol. (5), No (3), Summer 2020 \\ ISSN 2518-6566 (Online) - ISSN 2518-6558 (Print)}

curriculum designer, which is a Macmillan company. So, the students need the instructions about this skill that is available in their books and teachers' book.

6. The approach of SS in the Kurdistan region is the communicative approach, which is focused on the student-centered center, intervention technology with teaching enhanced this perspective.

7. Giving online feedback on their improvement encourage the students to be confident in their capacity to deal with listening skill problems hence it will be a positive washback, as well as it helps the teacher to judge where the students' level is going and how they should be guided.

8. Sunrise 10 provide great listening activities and tasks to implement inside the classroom or outside class through Audio CD transcribed, Students' book and Sunrise website that are available for all schools, the teachers and students use them freely.

9. The activity book is checked by the researcher regularly; it includes a great extend in activities and tests without any allusion of listening skills and subskills to practice while in students' book over $16 \%$ devoted for this language skill.

10. Some of the technological devices are available in urban schools, but they do not work well and affordable in addition to the problem of electricity and internet connection. Thus, it is the Government's responsibility to provide devices for all public schools.

11. In the public school, there is no enough space for practicing a listening skill, due to the large class with full of students, teaching duration (the lesson and semester duration are not convenient to achieve the aims well in the public schools, due to the interruption because of the holidays) 


\section{QALAAI ZANISTSCIENTIFIC JOURNAL \\ A Scientific Quarterly Refereed Journal Issued by Lebanese French University - Erbil, Kurdistan, Iraq \\ Vol. (5), No (3), Summer 2020 \\ ISSN 2518-6566 (Online) - ISSN 2518-6558 (Print)}

12. There are some hindrances/hampers are still existed in the Kurdish community to use the technological devices by preparatory phase students, especially at home because of their age (adolescent).

13. Generally, all the students are cheerful with integration technology with their lessons.

\subsection{Recommendations}

In accordance with conclusions, It is recommended that

1. LC be focused on as an active skill such as giving more attention in the teaching and more time should be allocated for its practice more and more complex subskill as they develop, either inside the lesson or outside.

2. The English language should be tested as a language test which comprises listening skill and sub-skills, (while it tested as a subject and its format cannot be considered as a communicative test), to the exams will be a means of learning and helps to improve students' language skills especially listening.

3. Preparatory teachers have to shift from traditional approaches of teaching into a modern way or instructional process encompassing technological in order to renovate their teaching style.

4. MOE has to provide different technological input devices for the public schools, and providing electricity can solve many problems of using technology in addition to internet connection after this step

5. Providing some useful applications to practice language skills, especially LC at home is another suggestion for the MOE and at least finding free applications and programs by the teachers to improve their students' language skill with LC to more consider about this point the teacher can give them homework related to LC, through listening to realia with authentic language (particularly in the holidays. So, as to avoid the teaching interruption, here the teacher can get benefit from 


\section{QALAAI ZANISTSCIENTIFIC JOURNAL \\ A Scientific Quarterly Refereed Journal Issued by Lebanese French University - Erbil, Kurdistan, Iraq \\ Vol. (5), No (3), Summer 2020 \\ ISSN 2518-6566 (Online) - ISSN 2518-6558 (Print)}

technology devices. Besides, application to teach them electronically) then evaluate and motivate those students who are active to use the technology by rewarding them from oral scores or even send an appreciation statement through school group on mobile.

6. Teachers need to be familiar with learning outcomes and objectives of utilizing and integrating technology with teaching English language skills such as LC.

7. Teachers and students are recommended to conduct continuous training courses and workshops about technology to avoid from technophobia. Besides, some online publications have to be issued by MOE to deal with the recent trends and development to teaching English as FL/SL, where the teachers exchange their ideas and their questions to be answered by specialists.

8. It will be a great idea the computer teachers have an accord with the English teachers to teach students an advantageous program to enhance their capacity to use technology appropriately.

9. School staff and supervisor should help the English teachers to pave the way of the school's atmosphere to use technology by the teachers. For that reason, they are decreasing students' number in the large classes. The teachers are recommended as well to arrange the classroom by making groups, fixed some tips of LC with technology to decorate the specific class to practice LC, and it should be far from noise pollution.

10. Students' parents are also recommended to educate and literate themselves to help their students to use technology for learning the purpose, not just electronical games or chatting and provide the devices for the students at home, whenever their teacher asked them to use any application for practice.

11. MOE and Macmillan company should think about the content of activity book to include some drills about $L C$, in order to oblige students to use audio $C D$ at home once more. 


\section{QALAAI ZANISTSCIENTIFIC JOURNAL \\ A Scientific Quarterly Refereed Journal Issued by Lebanese French University - Erbil, Kurdistan, Iraq \\ Vol. (5), No (3), Summer 2020 \\ ISSN 2518-6566 (Online) - ISSN 2518-6558 (Print)}

12. The relevant authorities should find some solutions for the obstacles that the teacher mention.

\section{REFERENCES}

Anon. (2019). Raz-kids. Retrieved April 7, 2019, from www.raz-kids.com

Bond, C. D. (2012). An Overview of Best Practices to Teach Listening Skills. The Intl. Journal of Listening, 26(1), 60-63.

Clarke, J. R. (2005). Research models and methodologies (First ed.).

Heaton, J. (1988). Writing English Language Tests (Second Edition ed.). New York: New York : Longman.

Johnson, K., \& Johnson, H. (1999). Encyclopedic Dictionary of Applied Linguistics (Second Edition ed.). Oxford: Oxford: Blackwell Publisher Ltd.

Kaplan, S. (2015). Mixing Quantitative and Qualitative Research (First ed.). Toronto: Toronto University Pree.

Sheir, A. A., Eltomy, N. A., \& Mostafa, H. (2013). The Effectiveness of Using Technology in Teaching Listening to Libyan Preparatory School Students. This Paper is Based on The Researcher's Thesis Submitted in Fulfillment of the Requirement for the Degree of Ph.D. in Education Curriculum and Instruction.

Sultan, A. I., \& Sharif, H. A. (2013). The Efficiency of Teaching Listening Comprehension of "Sunrise Series" in Erbil Governorate. The Journal of the Literary Literature, 1(16), 1-42.

Sunrise10. (2009). Students' Book. Erbil: Macmillan Publisher Limited.

Zhawawi, Q. M. (2019). The Implementation of the Principles of Constructivism in Teaching EFL to Kurdish University Students at Salahaddin University-Erbil. Ph.D. Dissertation, Salahaddin University-Erbil, Language Department, Erbil. 


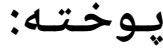

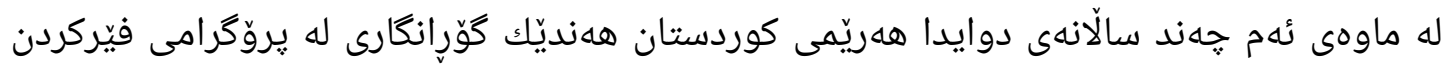
(يهروهرده) ئهنجامدا، له نيّوانياندا يهيروهكردن يان دانانى كوّرسيّكى نويّى تايبهت به وانهى / بابهتى ئينكليزى به ناوى (SUNRISE)، به مهبهستى بهرهويِيشجوونى تواناى قوتابيان له فيّربوونى زمانى

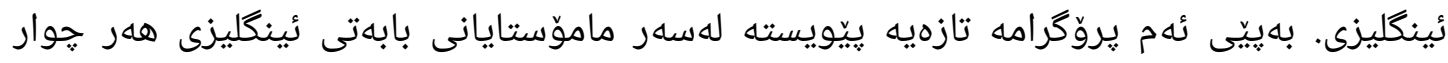
كارمهييهكانى زمان (خويندنهوه، نووسين، كويّكرتن، قسهكردن) گرنكى يِيبدهن و تاقيكردنهوهى تيّدا

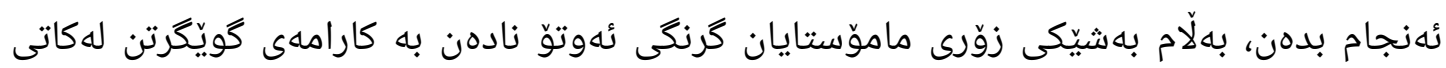
وانهوتنهوهدا، لهبهرئهوهى هوّيهكانى فيّركردن لهم كارامهييه تا رِادهيهكى زوّر دهستهبهرنهكراوه و كوّنن سهرهنجى قوتابيان لِاناكيّىى و له ههمانكاتدا يِيشكهوتنى ته كنهلوَجيا تيّدا روّلّ نابينى. لهمهوه ئهوهبهدى دهخرى كه قوتابيان ئازوومهند نيين له فيّربوونى كارامهى بيستن له وانهى ئينكليزى و قوتابيان مهيلى فهرموّشكردنى ئهم كارامهيه دهكهن لهبهر ئهم هوّكارانهى كه لهسهرهوه باسمان كرد. كه ئهمهش بووه هوّيى ئهوهى كه تويّزَهر لِيّكوّلينهوه بكات لهزيّر ناونيشانى(كاريكَهرى ئاويّته كردنى تهكنهلوَزيا له وتنهوهى شارهزايى بيستن به قوتابيانى كورد قوّناغى ئامادهيى) به مهبهستى جوّنيهتى بهكارهيّنانى تهكنهلوّجياى يِيّشكهوتوو و سهردهميانه بوّ هاندان و راكيّشانى ئارهزووى قوتابيان بوّ بهرهو يِيشجونى كارامهى بيستن لهوانهى زمانى ئينكليزى كه يهكيكه له بنهما سهرهكى و كرنكهانى فيّربوونى زمان.

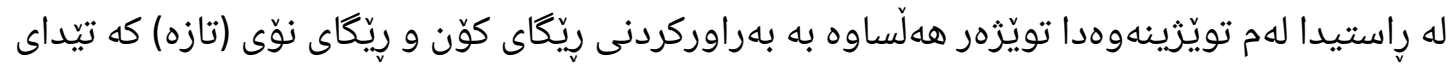
هوّيه كانى بهكارهيّنانى تهكنهلوَجيا بهكارهاتووه لهو قوتابخانهى كه تويّزهر وهكو نموونه وهريكرتووه. وهكو ههوليّك بوّ نيشاندانى لايهنه باش و بهرههمدارهكانى ريّبازى نوّى لهسهر يهرييّدانى كارامهى بيستن لهلايهن قوتابيانهوه، كه ئهمهيش بهشيّك بووه له گريمانهى سهركى تويّزينهوهكه بهيشت 


\section{QALAAI ZANISTSCIENTIFIC JOURNAL}

A Scientific Quarterly Refereed Journal Issued by Lebanese French University - Erbil, Kurdistan, Iraq

Vol. (5), No (3), Summer 2020

ISSN 2518-6566 (Online) - ISSN 2518-6558 (Print)

بهستن به ليّكوّلينهومى نيمجه ئهزموونى كه ريّكايهكى زانستى دروسته بوّ سهلماندن و نهسهلماندنى كريمانهكانى ئهم جوّره تويَزينهوانه .

بوّ سهلماندنى گريمانهى تويَزينهوه تويّزهر تاقيكردنهوه (ههلَّهنكاندى )يِيش وهختهو ياش وهختهى يهيرهو كردووه له دارشتن و رخستنى لِيكوّلينهوهكى. ههر بوّ ئهم مهبهسته تويّزهر زمارهيهك|( نموونهيه ك) له قوتابيانى قوتابخانهيهكى ئامادهى كجان وهركرتووه وهكو نموونه بوّ سالّى خوّيَندنى 2019-2018، كه زمارهى قوتابيهكان 40 قوتابى بوو له قوّناغى 10، له سهرتادا قوّتابيهكان تاقيكردنهوهيهكى سهرهتاييان بوّكرا بوّ ديارى كردنى ئاستيان، و لهسهر بنهماى زانستى ئامارى كران بهدوو گرويى سهرهكى(گرويى كونتروّل و گرويى ئهزموونى) و ئهم دوو گرويه بوّ ماوهى 8 ههفته به به بهردهوامى ئاراسته دهكران، گرويى كوّنتروّل به ريّكاى كوّن تيّبيينيان وهردهكرت و گرويى ئهزموونى بهريّكاى تازه و به بهكارهيِنانى ئامرازهكانى تهكنهلوَجيا يِيشكهوتوو لهناو يوّل و لهمال و راهيّنان و تيّبينيان يِيدهدرا، وه له كوّتاى ماوهكه دا ههردوو گروب تاقيكردنهوهيان بوّ كرا. لهو ريّكايهوه تويّزهر داتاكانى كوّكردوّتهوه، و بهمهبهستى شيكردنهوهى داتاو زانياريهكان تويّزهر يشتى به ئامرازه ئامارييهكان بهستووه و به بهكارهيّنانى بروّكرامىSPSS-V24. سهرهكيترين ئهنجامى تويّزينهوه كه تويَزهر يِيِكهيشتووه بهكارهيّنانى تهكنهلوَيا بهشيّوهكى ئاشكرا و رِوون يارمهتى بهرزكردنهوهى شارهزايى بيستنى قوتابيانى كورد دهدات و ئهوهى كه قوتابيانى ناو گرويى ئهزموونين زوّرتر باشتربوون له بهراورد له گهل قوتابيانى ناو كرويى كوّنتروّلّ له شارهزاييه لاوهكيهكانى بيستندا. 


\section{QALAAI ZANISTSCIENTIFIC JOURNAL}

A Scientific Quarterly Refereed Journal Issued by Lebanese French University - Erbil, Kurdistan, Iraq

Vol. (5), No (3), Summer 2020

ISSN 2518-6566 (Online) - ISSN 2518-6558 (Print)

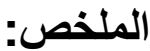

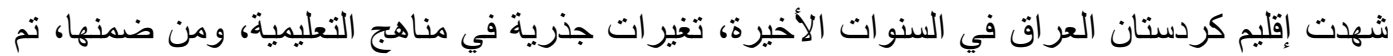

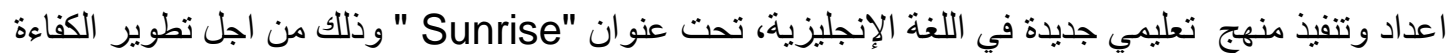

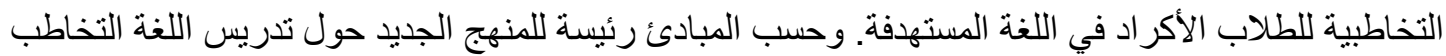

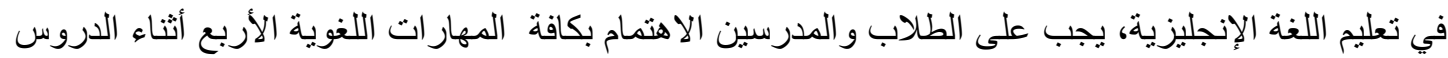

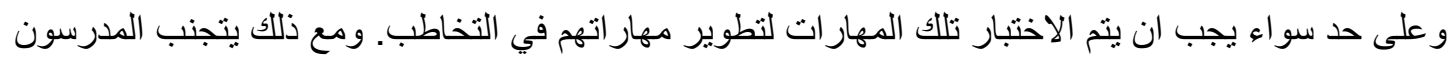

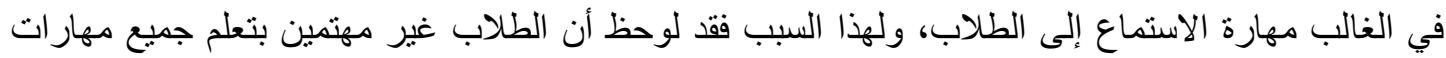

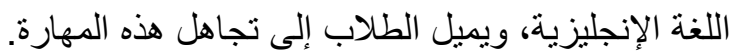

ان هذه الدر اسة و التي تحمل عنو ان "تأثير دمج الكنلوجيا في تدريس مهارة الاستماع إلى الطلاب الأكاديميين في في الإني

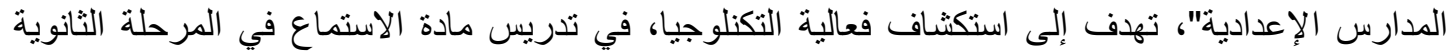

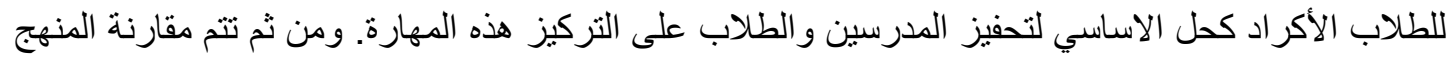

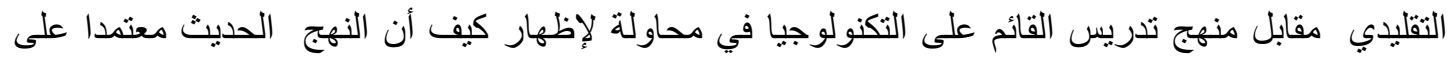

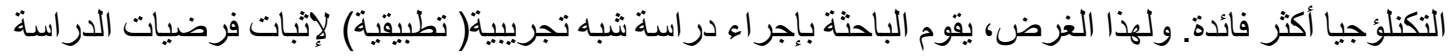

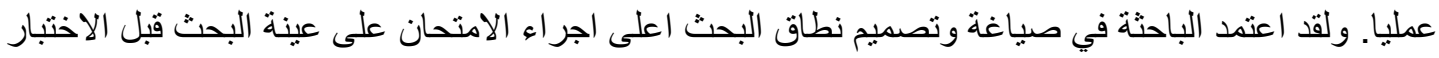

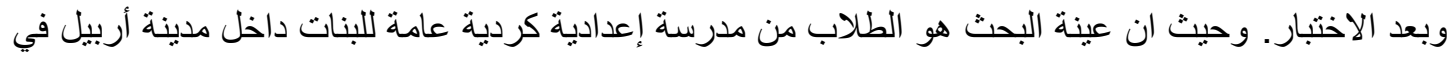

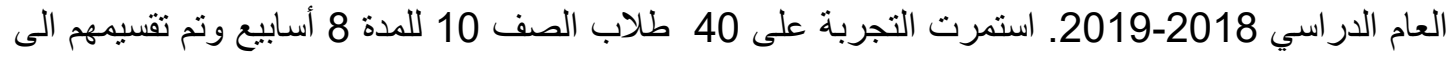

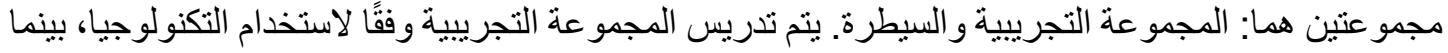
تم تدريس المجمو عة السيطرة وفقا استخدام المنهج التقليدي.

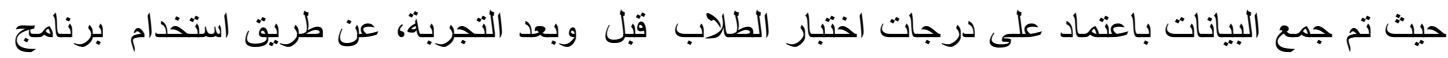

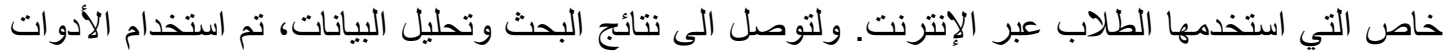

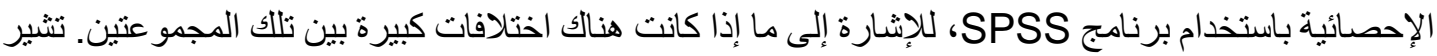

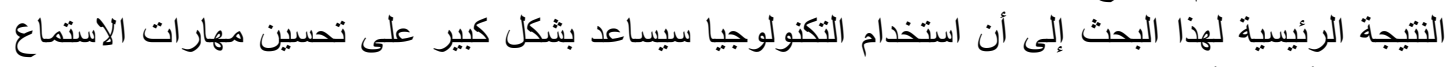
للطلاب الأكر اد وأن المجمو عة التجريبية تفوقت على مجمو عة التحكم في مهار ات الاستماع الفرعية لايهر. 